\title{
Memória e Imagem
}

Eduardo Roberto Jordão Knack

Rita Juliana Soares Poloni

Gaston Bachelard (2008, p.3), em sua obra "A poética do espaço", coloca a seguinte questão: "como uma imagem por vezes muito singular pode revelar-se como uma concentração de todo o psiquismo?". O filósofo assume que algumas imagens são tão fortes que causam um impacto profundo no observador, produzindo e despertando uma miríade de sentimentos que são desencadeados nessa relação entre o sujeito que observa e o objeto observado. Essas emoções só despertam nesse momento por guardarem uma íntima relação com a memória.

Emoções são despertadas pelo reconhecimento das imagens. Bergson (1990) chama a atenção para a relação entre a percepção, reconhecimento e as imagens. Não conseguimos compreender a matéria, apenas percebemos uma imagem do mundo material - toda a matéria do universo seria uma única imagem, é o homem que divide o mundo em diferentes imagens.

Bergson preocupa-se em como os indivíduos reconhecem as imagens - 0 reconhecimento ocorre por duas maneiras (ambas passam pela percepção) - na própria ação, no movimento, quando emana dos objetos - por representação, quando emana do indivíduo, o que implica um trabalho do espírito, que busca no passado e na memória representações das imagens úteis a situação presente.

Halbwachs (1976; 1990) busca uma abordagem social da memória, imprimindo outra dimensão para pensarmos a relação entre a memória e as imagens. A partir de suas considerações, as imagens podem ser entendidas como importantes elementos dos quadros sociais da memória, utilizadas pelos grupos sociais para atualizar e ressignificar a memória coletiva. A dimensão social envolve pensar a circulação e recepção das lembranças, bem como os seus suportes, que vão desde fontes escritas, até materiais e visuais.

Colacrai (2010) alerta para o caráter positivista das teorias da memória de Halbwachs, o que o levou a ignorar problemas e conflitos sociais da memória em uma dimensão social. Autores como Pollak (1989), Connerton (2008) e Candau (2004) percebem a complexidade que envolve pesquisar a memória. Pollak explora os 
silêncios, os subterrâneos e recalques da memória, Connerton explora os diferentes tipos de esquecimentos, tão importantes para pensar a memória como a lembrança e Candau elabora conceitos fundamentais, como metamemória e os sociotransmissores.

Cada uma dessas abordagens da memória coloca outros problemas para uma reflexão sobre a memória e a imagem. Os silêncios e esquecimentos inerentes na própria composição de uma imagem são possíveis de serem explorados a partir desses autores. Candau problematiza ainda mais essa relação ao questionar a possibilidade da existência de uma memória compartilhada. O conceito "metamemória" explora esse aspecto, pois quando a lembrança entra na esfera da linguagem, seja pela fala, pela escrita ou por outra forma de expressão, ela já é reformulada.

Além desses aspectos, Candau (2012) também insere o problema do fenômeno que classificou como "iconorréia", a proliferação de imagens na nossa sociedade contemporânea conduz a uma industrialização do esquecimento. Essa saturação pode levar a erosão de memórias sociais, especialmente com a multiplicação de memória mecânicas, artificiais que, embora produzidas como auxiliares contra o esquecimento, nos eximem como depositários da memória.

Isso implica pensar na construção de uma imagem e em sua capacidade de despertar emoções dentro de uma relação entre observador e objeto observado. A imagem, construída, elaborada pelos sujeitos, envolve a mobilização da memória, mas estas lembranças são reformuladas ao serem expressadas como metamemória. Outra questão que as considerações de Candau possibilitam é entender o papel que a imagem pode assumir como sociotransmissor. Nesse sentido, a imagem atuaria como um indicador exterior contra o esquecimento, um "reminding", como define Ricoeur (2007), no entanto sua profusão contemporânea coloca em xeque essa função.

Existem, portanto, uma série de questões que podem ser exploradas a partir da relação entre memória e imagem. O objetivo do presente dossiê não é esgotar ou abordar cada um desses problemas, mas apresentar um conjunto de trabalhos que permitam perceber como essa memória e imagem estão fortemente relacionadas. Dessa forma, reuniu artigos que exploraram a imagem como uma profícua fonte de pesquisa, bem como trabalhos que, a partir de uma imagem, se debruçaram sobre uma complexidade social, cultural e política, envolvendo usos, circulações e políticas públicas da memória e do patrimônio. 
O dossiê inicia com o artigo "Silêncios no pampa: breves pontuações sobre a imagem do gaúcho na pintura rioplatense e brasileira", de Luciana da Costa de Oliveira. Os "silêncios no pampa" sobre a imagem do gaúcho nas pinturas de Aldo Locatelli, Cesáreio Bernaldo de Quirós, Pedro Figari e Pedro Weigärtner são fundamentais para refletir sobre a composição da imagem do gaúcho e seu ideal em uma memória social na região abordada. A autora se dedica a refletir sobre os silêncios em torno das fontes visuais a partir de diversos elementos em seu entorno, seja aqueles que compõem a obra, ou que envolvem o artista.

Darlan De Mamann Marchi e Olivia Silva Nery apresentam o artigo "A memória e os objetos: interpretações sobre o filme brasileiro 'O palhaço'", discutindo questões em torno da memória e identidade. $O$ trabalho se debruça sobre uma análise do roteiro e o papel dos objetos na composição da narrativa fílmica. As emoções estão associadas, no filme, com certos objetos (imagens), como o ventilador e o chapéu. Não apenas o filme (imagem em movimento), como outros elementos imagéticos dessa narrativa visual são o foco da análise dos autores.

O artigo "Moneda, imágine y poder. El ejemplo de los Maravedíes", de Cláudio Umpierre Carlan, aborda elementos que compõem a numismática, sua organização, difusão e circulação. Assim, a moeda, como documento, pode informar sobre os mais variado aspectos de uma sociedade, pois é um objeto palpável com uma série de elementos imagéticos. Seu objeto de estudo são os "maravedíes", cunhados pelo rei de Castilla, alfonso VI (1040-1109).

Milagros Elena Rodríguez contribui para o dossiê com o artigo "La fotografia como creadora de la imagen de un destino turístico cultural sustentable en el Parque Nacional Mochima, Estado Sucre". Nesse trabalho, a autora analisa como a fotografia cria e difunde imagens e símbolos turísticos culturais a partir de um caso específico, um parque nacional na Venezuela, relacionando três elementos - patrimônio, turismo e cultura.

"O jardim dos refugiados", de Rui Gomes Coelhos aborda a relação entre memória e imagem a partir da paisagem. Os refugiados levam uma vida itinerante, o que torna difícil pensar nessa relação. Porém, o autor demonstra que os jardins podem ser concebidos como a projeção de uma ordem, de enraizamento, ou seja, para os refugiados é uma forma de rememorar o lar que foi deixado para trás, mas também uma forma de transformar as duras condições que enfrentam. 
Além do dossiê, o presente número ainda conta com os artigos "Vila União dos Operários, Canoas, RS: Iuta por moradia e habitabilidade (1980-2014), de Ivo Fiorotti, Cleusa Maria Graebin e Lucas Graeff, constitui uma história social urbana das lutas por moradia ocorridas no processo de ocupação de um terreno que deu origem a uma vila operária no município de Canoas. O trabalho "Política pública de preservação ferroviária em Bauru (SP): os desdobramentos da criação de programas nacionais e conselhos representativos na década de 1980", de Sérgio Ricardo Losnak e Eduardo Romero de Oliveira, empreende uma análise das políticas públicas de preservação patrimonial no estado de São Paulo, especificamente na cidade de Bauru. Finaliza a edição o ensaio "La imagen como memoria: Palestina patrimonio invisible", de Jenny González-Muñoz, abordando a ilustração como elemento importante da construção da memória social que envolve agressões a povos historicamente perseguidos.

Os artigos que compreendem o presente número da Revista Memória em Rede constituem uma leitura importante não apenas para pesquisadores que se dedicam ao estudo das relações entre memória e imagem. São trabalhos que envolvem diferentes dimensões teóricas e metodológicas da pesquisa em ciências humanas, e justamente por isso podem contribuir para investigadores de diferentes áreas observarem caminhos trilhados em diferentes esferas e escalas de análise. E, além do dossiê, os artigos e ensaios que complementam o número proporcionam uma visão sobre outros temas/problemas que, dentro do escopo da revista, fornecem exemplares de pesquisas que podem ampliar horizontes sobre uma série de questões das ciências sociais. Esperamos que os artigos aqui reunidos possam abrir novos horizontes, indicar caminhos e objetos para futuras pesquisas, e, com certeza, aprofundar o conhecimento daqueles que já se dedicam aos temas abordados.

Desejamos uma ótima leitura para todos!

\section{Referências:}

BACHELARD, Gaston. A poética do espaço. 2.ed. São Paulo: Martins Fontes, 2008.

BERGSON, Henri. Matéria e memória. Ensaios sobre a relação do corpo com o espírito.São Paulo, Martins Fontes, 1990.

CANDAU, Joël. Conflits de mémoire: pertinence d'une métaphore? In:BONNET, V'Wronique (sousladirection de). Conflits de mémoire. Paris, Éditions Karthala, 2004. 
CANDAU, Joël. Memória e identidade. São Paulo: Contexto, 2012.

COLACRAI, Pablo. Releyendo a Maurice Halbwachs. Una revisión del concepto de memoria colectiva". In: La Trama de la Comunicación, V. 14, 2010.

CONNERTON, Paul. Seven types of forgetting. In: Memory Studies, 2008

HALBWACHS, Maurice. Les cadres sociaux de la mémoire. Paris: Mouton, 1976.

HALBWACHS, Maurice. A memória coletiva. Rio de Janeiro: Vertice, 1990.

POLLAK, Michel. Memória, Esquecimento, silêncio. In: Estudos históricos, vol.2, n.3, 1989.

RICOEUR,Paul. A memória, a história, o esquecimento. Campinas: Editora da Unicamp, 2007 